\title{
Comparison between two layer and three layer repair of episiotomy
}

\section{Seetha Garag, Chandana Murthy S. R.*, Naveen S. B.}

Department of Obstetrics \& Gynaecology, Karnataka Institute of Medical Science, Hubli, Karnataka, India

Received: 02 November 2015

Revised: 10 November 2015

Accepted: 14 December 2015

\section{*Correspondence:}

Dr. Chandana Murthy S R,

E-mail: chandana.ramchandra@gmail.com

Copyright: (C) the author(s), publisher and licensee Medip Academy. This is an open-access article distributed under the terms of the Creative Commons Attribution Non-Commercial License, which permits unrestricted non-commercial use, distribution, and reproduction in any medium, provided the original work is properly cited.

\begin{abstract}
Background: The study was done to compare the two layer episiotomy suturing and three layer episiotomy suturing with regard to time taken to suture, number of suture material required and complications at suturing site postnatally. Methods: This study was conducted in the Gynaecology and Obstetrics department of Karnataka Institute of Medical Science, Hubli, Karnataka, India from 1st March 2015 to 30th April 2015.

Results: The two layered technique required lesser suture material and lesser time compared to the three layer techhnique.

Conclusions: In our study two layer techniques took lesser time and lesser suture material than three layer technique.
\end{abstract}

Keywords: Episiotomy, Suture material, Two layers

\section{INTRODUCTION}

Episiotomy is a surgically planned incision on the perineum and posterior vaginal wall during the second stage of labour. It is derived from the Greek word "epision" meaning pudenda and "tom" meaning to cut. The episiotomy rates in primiparas vary from $67 \%$ to $92.3 \%{ }^{1}$ The rationale for routine episiotomy is based on two foundation arguments: that episiotomy reduces perineal trauma and that it prevents subsequent pelvic relaxation. Episiotomy has witnessed ups and downs during the evolution of medical sciences. Episiotomy is reserved for cases where perineum is likely to torn, rigid perineum, complicated childbirths, good size baby and assisted deliveries. ${ }^{2}$ In practice mediolateral episiotomy is preferred over median for fear of extension into the anal sphincter complex. ${ }^{3,4}$

In our study we compare the two layer repair of mediolateral episiotomy with three layer repair.

\section{METHODS}

This study was conducted in the Gynaecology and Obstetrics department of Karnataka Institute of Medical
Science, Hubli, Karnataka, India from 1st March 2015 to 30th April 2015. A total of 100 women of vaginal deliveries were included. Of this 50 were assigned to group Group 'A' which included those with three layer suturing technique-mucosa, muscle and skin were closed with no 1 vicryl, mucosa closed in a continuous locking fashion, muscle closed by interrupted sutures and skin with vertical mattress sutures. Group ' $B$ ' included those with two layer technique-vaginal mucosa and muscle was stitched together in continuous interlocking manner and skin was closed with vertical mattress sutures.

\section{Inclusion criteria:}

Primigravida following-

- full term normal delivery

- singleton pregnancy

- vertex presentation

- with medio lateral episiotomy

\section{Exclusion criteria:}

- instrumental delivery

- previous existing local infectious lesions

- hemoglobin $<8 \mathrm{gm} \%$ 
- body mass index $>25 \mathrm{~kg} / \mathrm{m}^{2}$

- preexisting medical disorders like heart disease, PIH and renal disease

- previous scar on uterus

- third degree and fourth degree vaginal tear

This study was double blinded. One group of researchers sutured episiotomies and those who collected the data about postnatal patients were unaware of the technique used for that particular patient. Patients were also not aware of technique used. Immediately after repair of the perineum, the numbers of suture strands used were counted and the time taken for the repair was recorded. Three days post-partum, before discharge, the participants were asked about severity of pain, discomfort at defecation and any complications at the sutured site like edema, induration, wound dehiscence, infection, hematoma, was examined. If required re-suturing was done.

The visual analogue scale was used to define the severity of pain:

None: 0-2, Slight: 3-4, Moderate: 5-7, Severe: 8-10.

The results were analyzed using independent' $t$ ' test.

\section{RESULTS}

Table 1: Time for suturing with relation to number of layers in episiotomy.

\begin{tabular}{|c|c|c|c|c|c|}
\hline & $\begin{array}{l}\text { No of } \\
\text { lay-ers }\end{array}$ & $\mathbf{N}$ & Mean & $\begin{array}{l}\text { Std. } \\
\text { Devi- } \\
\text { ation }\end{array}$ & $\begin{array}{l}\text { Std. } \\
\text { Error } \\
\text { Mean }\end{array}$ \\
\hline \multirow{2}{*}{$\begin{array}{l}\text { Time } \\
\text { for } \\
\text { sutu- } \\
\text { ring }\end{array}$} & 2 & 50 & $\begin{array}{l}508.0 \\
000\end{array}$ & $\begin{array}{l}79.2631 \\
9\end{array}$ & $\begin{array}{l}11.20 \\
951\end{array}$ \\
\hline & 3 & 50 & $\begin{array}{l}571.4 \\
000\end{array}$ & $\begin{array}{l}80.0066 \\
3\end{array}$ & $\begin{array}{l}11.31 \\
465\end{array}$ \\
\hline
\end{tabular}

Independent $\mathrm{t}$ test value: -3.981 P value: 0.000 (Highly

Significant)

CI: -95.00692 to -31.79308

Table 2: Number of suture material required with relation to number of layers in episiotomy.

\begin{tabular}{|l|lll|}
\hline \multirow{2}{*}{$\begin{array}{l}\text { No of suture } \\
\text { material required }\end{array}$} & \multicolumn{2}{l|}{ No of layers } & Total \\
\hline 1 & 2 & 3 & \\
\hline 2 & 49 & 42 & 91 \\
\hline Total & 1 & 8 & 9 \\
\hline
\end{tabular}

Independent $\mathrm{t}$ test : -2.497 $\mathrm{P}$ value-0.014 (Significant) CI: -0.251 to -0.029

A total of 100 women underwent episiotomy suturing. There was no statistically significant difference between the two groups with respect to age, birth weight, severe pain and complications. The two layered technique required lesser suture material $(\mathrm{P}$ value-0.014) and lesser time ( $\mathrm{P}$ value: 0.000 ) compared to the three layer technique (Table 1-7).
Table 3: Age with relation to number of layers in episiotomy.

\begin{tabular}{|lllll|} 
& \multicolumn{3}{c}{$\begin{array}{l}\text { No of } \\
\text { layers }\end{array}$} & Total \\
& & 2 & 3 & \\
\hline \multirow{3}{*}{$\begin{array}{l}\text { Age } \\
\text { classification }\end{array}$} & 1.00 & 28 & 21 & 49 \\
\hline Total & 2.00 & 14 & 24 & 38 \\
\hline & 3.00 & 8 & 3 & 11 \\
\hline & 4.00 & 0 & 2 & 2 \\
\hline
\end{tabular}

(Lowest thru 20=1) (21 thru 23=2) (24 thru 28=3) (29 thru Highest=4).

Table 4: Group statistics.

\begin{tabular}{|llllll|}
\hline & $\begin{array}{l}\text { No } \\
\text { of } \\
\text { lay- } \\
\text { ers }\end{array}$ & N & Mean & $\begin{array}{l}\text { Std. } \\
\text { deviat } \\
\text { ion }\end{array}$ & $\begin{array}{l}\text { Std. } \\
\text { Error } \\
\text { Mean }\end{array}$ \\
\hline $\begin{array}{l}\text { Age } \\
\begin{array}{l}\text { Cla- } \\
\text { ssifica } \\
\text { t-ion }\end{array}\end{array}$ & 2 & 50 & 1.6000 & 0.75593 & 0.10690 \\
\cline { 2 - 6 } & 3 & 50 & 1.7200 & 0.75701 & 0.10706 \\
\hline
\end{tabular}

Independent $\mathrm{T}$ test value: $-0.793, \mathrm{P}$ value: $0.430, \mathrm{CI}:-0.42024$ to 0.18024

Table 5: Duration of hospital stay in relation to number of layers in episiotomy.

\begin{tabular}{|lllll|}
\hline & & \multicolumn{2}{l}{ No of layers } & Total \\
& & 2 & 3 & 4 \\
\hline $\begin{array}{l}\text { Duration of } \\
\text { hospital stay }\end{array}$ & 2 & 3 & 1 & 96 \\
\cline { 2 - 5 } & 3 & 47 & 49 & 100 \\
\hline Total & & 50 & 50 & $9.118-$
\end{tabular}

Independent T Test value:-1.016, P Value: 0.312, CI: -0.1180.038

Table 6: Wound dehiscence with relation to number of layers in episiotomy.

\begin{tabular}{|lllll|}
\hline & & \multicolumn{2}{c}{ No of layers } & Total \\
\cline { 2 - 5 } & & 2 & 3 & \\
\hline Wound & 0 & 50 & 47 & 97 \\
\cline { 2 - 5 } dehiscence & 1 & 0 & 3 & 3 \\
\hline Total & & 50 & 50 & 100 \\
\hline
\end{tabular}

Independent T Test value: -1.769 , P Value: 0.08(not significant) CI: $-0.128-0.008$

Table 7: Severe pain with relation to number of layers in episiotomy.

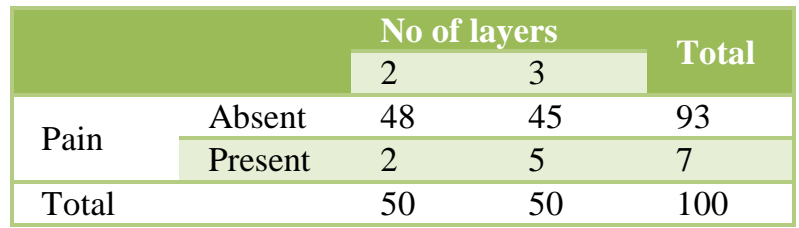

Independent T Test value: 1.172; P Value: 0.244; CI: -0.1620.042 


\section{DISCUSSION}

In this study, the differences between the 2 layer suturing group and the 3 layer suturing group were a reduction in repair time and use of less suture material.

Valenzuela $\mathrm{P}$ et al in a state hospital in Madrid, Spain where they also required significantly lesser time for continuous repair with $\mathrm{P}$ value of 0.017 . $^{5} \mathrm{Jafar} \mathrm{S}$ in 2009 in a RCT comparing single knot versus three layer repair of episiotomy confirmed that in interrupted sutures the thread is wasted every time a knot tied and the thread is cut concluding that continuous repair requires less thread $(\mathrm{P}<0.001){ }^{6}$

\section{CONCLUSIONS}

Thus in conclusion, two layer suturing technique for perineal closure is associated with lesser suture material requirement and lesser time taken for suturing. Therefore, the two layer suturing technique is recommended for repair of vagina and perineal muscles.

Funding: No funding sources

Conflict of interest: None declared

Ethical approval: The study was approved by the Institutional Ethics Committee

\section{REFERENCES}

1. Fernando A, Jose MB. Episiotomy rates in primipara in women in latin America: hospital based descriptive study. BMJ. 2002;24(7343):945-6.

2. Kettle C, Hills RK, Jones P, Darby L, Gray R, Johanson R. Continuous versus interrupted perineal repair with standard or rapidly absorbed sutures after spontaneous vaginal birth: a randomised controlled trial. Lancet. 2002;359(9325):2217-23.

3. Kudish B, Blackwell S, Mcneeley SG, Bujold E, Kruger M, Hendrix SL, et al. Operative vaginal and midline episiotomy: a bad combination for perineum Am JOG.2006;195:749.

4. Coats PM, Chan KK, Wilkins M, Beard RJ. A comparison between median and mediolateral episiotomy BJOG. 1980;87(5):408-12.

5. Valenzuela P, Puente S, Valero JL, Azorin R, Ortega R, Guijarro R. Continuous Vs interrupted sutures for repair of episiotomy. BJOG. 2009;11(3):436.

6. Jafar S. Comparison of single knot Vs three layer technique of perineal repair after vaginal delivery. Journal of Turkish-German associates. 2008;9(3):129-33.

Cite this article as: Garag S, Chandana Murthy SR, Naveen SB. Comparison between two layer and three layer repair of episiotomy. Int J Reprod Contracept Obstet Gynecol 2016;5:140-2. 